\title{
ТЕОРЕТИЧЕСКОЕ ОСМЫСЛЕНИЕ ПРОФОРИЕНТАЦИИ ШКОЛЬНИКОВ В КОНТЕКСТЕ СОЦИОЛОГИЧЕСКОГО ПОДХОДА
}

\author{
(c) 2018 Ходыкин Александр Владимирович \\ НИИ социальных технологий \\ Самарский национальный исследовательский университет имени академика С.П. Королева \\ 443086, Россия, г. Самара, ул. Московское шоссе, д. 34 \\ E-mail: avhod@yandex.ru
}

В статье выделены и подробно охарактеризованы следующие направления теоретического осмысления профориентации школьников: профориентация как социокультурный процесс, как социальный институт, как социальная деятельность и как система социальных отношений.

Ключевые слова: профориентация, школьники, процесс, институт, деятельность, социологический подход, подходы к профориентации, исследования профориентации.

Профориентация школьников представляет собой сложный комплексный социальный феномен, имеющий междисциплинарный характер и включающий в себя элементы педагогики, психологии, философии, экономики, социологии, медицины и физиологии. Методология перечисленных наук становится базой для формирования соответствующих научных подходов к профориентации школьников [1].

Большое значение профориентации школьников для качественной подготовки трудовых резервов общества, воспроизводства его социально-профессиональной структуры и его развития в целом обусловливает актуальность исследований профориентации школьников с социологических позиций. Подобные исследования проводились ещё такими классиками социологии, как Карл Маркс и Толкотт Парсонс [2], [3]. В настоящее время социологическая наука содержит широкий круг исследований, создающих базу для формирования социологического подхода к исследованию профориентации школьников. Вместе с тем, проводимые в рамках социологической науки исследования профориентации школьников нуждаются в теоретической систематизации.

Фокус внимания теоретических исследований профориентации школьников в контексте социологического подхода, на наш взгляд, следует сосредоточить на выявлении новых перспективных направлений исследования профориентации школьников, а также на теоретическом осмыслении и систематизации комплекса эмпирических исследований профориентации школьников в контексте социальной системы и социальных отношений, характер- ных для данного общества. Под теоретическим осмыслением в современной науке понимается вид познавательных процессов, которые основаны на вербально-логической функции и характерны для теоретического общества, а также имеют соответствующую им динамическую смысловую систему [4]. Анализ научных источников и результатов эмпирических исследований позволяет сделать вывод о том, что, с точки зрения социологического подхода, профориентация школьников может быть теоретически осмыслена по следующим ключевым направлениям: профориентация как социокультурный процесс, как социальный институт, как социальная деятельность и как система социальных отношений. Более подробно охарактеризуем каждое из перечисленных направлений.

Профориентация как социокультурный процесс представляет собой осуществляющийся в контексте социокультурных условий данного общества процесс профессионального самоопределения школьника путём выбора им рода профессиональной деятельности, стратегии профессионального развития и желаемого профессионального и социального статуса. Социокультурный характер процесса профориентации проявляется формированием трансформирующегося комплекса социокультурных факторов, отражающих социокультурные условия профориентации школьников. К таким факторам на макросоциальном уровне следует отнести экономические, политические, социальные и культурные условия общества, а также текущую и прогнозируемую ситуацию на рынке труда и его особенности, моду и представления о престижности профессий, сложившиеся в данном обще- 
стве. На микросоциальном уровне на процесс профориентации школьника оказывают влияние непосредственные субъекты его профориентации, такие как школа или семья, а также социально-экономические условия жизни, социальный и профессиональный статус родителей, уровень дохода семьи, семейные ценности и традиции и т.д. Следует отметить, что исследования социокультурного процесса профориентации школьников необходимо проводить с учётом анализа взаимодействия социальных явлений, характерных для профессионального самоопределения школьников, с социальными явлениями, характерными для трудовой сферы общества, в котором осуществляется процесс профессионального самоопределения.

Профориентация школьников как социальный институт в широком смысле - это исторически сложившаяся, экономически, политически, социально и культурно обусловленная, изменяющаяся под влиянием трансформации общества форма организации взаимодействия акторов профориентации школьников и социальной системы, в рамках которой она проводится, с целью эффективного воспроизводства профессиональной структуры общества, а также создания оптимальных условий для успешной профессиональной самореализации личности. В узком смысле - это форма организации деятельности по профориентации школьников, характерная для данного общества. Поскольку профориентация является одним из направлений социализации, институт профориентации школьников включён в сеть институтов их социализации, к которым относятся: школа, семья, система дополнительного образования, средства массовой коммуникации, общественные организации и т.д. Посредством института профориентации осуществляется организация и реализация государственной политики в области профориентационной работы со школьниками.

Профориентация школьников как социальная деятельность - это комплексная, научно обоснованная деятельность акторов профориентации, направленная на оказание школьнику содействия в выборе профессии, компромиссно удовлетворяющей его собственным социально-профессиональным интересам, интересам общества, государства и рынка труда. Изучение профориентации как социальной деятельности заключается в исследовании непосредственной работы акторов профориентационной деятель- ности по её организации и осуществлению для достижения её целей и задач. На микросоциальном уровне исследуется профориентационная деятельность непосредственных акторов профориентации: школьных психологов, специалистов-профориентаторов центров занятости и карьеры, специалистов центров профориентации и т.д. и социальные факторы, оказывающие на неё влияние. На макросоциальном уровне предметом изучения является деятельность должностных лиц и возглавляемых ими учреждений по созданию, организации и обеспечению функционирования общегосударственной системы профориентации. Исследованию организации и осуществления профориентационной деятельности посвящён комплекс российских научных исследований.

В контексте социологического подхода профориентация школьников исследуется и как система социальных отношений, возникающих в процессе профориентации между школьником и другими социальными акторами, осуществляющими его профориентацию или напрямую влияющими на процесс его профессионального самоопределения. Социальный процесс профориентации школьников протекает в контексте сети пронизывающих его социальных отношений, исследование которых даёт ключ к пониманию многих социальных аспектов профориентации. В контексте исследования системы социальных отношений, инкорпорированных в процесс профориентации, может быть изучено влияние мнения родителей на профессиональное самоопределение школьника в контексте системы отношений между школьником и его родителями и возможные конфликты, возникающие на основании разногласий по поводу профессионального выбора школьника; влияние личности профориентатора или иного лица, выполняющего его функции, а также влияние референтной группы, мнения авторитетного для школьника человека и мнений социального окружения школьника на результат его профориентации. Следует отметить, что на сегодняшний день в российской науке имеется выраженная недостаточность социологических исследований системы социальных отношений в контексте профориентации школьников, однако некоторые работы всё же можно выделить. Влияние отношений в семье, отношений с родителями и с социальным окружением на профессиональное самоопределение школьника обосновано в ра- 
боте В.А. Цвыка, исследующего профессиональное самоопределение в контексте профессионализации [5]. Количественные характеристики профессиональной преемственности поколений представлены в результатах социологического исследования социальной стратификации российского общества, проводившегося Институтом социологии РАН [6].

Подводя итоги работы, мы можем сделать вывод о наличии в рамках социологического подхода ряда ключевых направлений, систематизирующих теоретические представления относительно профориентации школьников. Анализ социокультурных условий общества, формирующих специфику протекающего в данном обществе процесса профориентации, даёт ключ к пониманию профориентации школьников как социокультурного процесса. Значение профориентации школьников как социального института раскрывается исследованиями формы организации профориентационной деятельности, проводимой сетью социальных институтов, осуществляющих социализацию школьников. Если институциональное направление профо- риентации школьников характеризует форму её организации, то деятельностное направление наполняет эту форму содержанием профориентационной деятельности социальных акторов. Изучение профориентации школьников как социальной деятельности даёт возможность выявить сущность, определить характеристики и обозначить направления работы социальных акторов по организации и проведению профориентации школьников. Анализируя профориентацию школьников как систему социальных отношений, инкорпорированных в процесс профориентации, мы можем охарактеризовать влияние особенностей сети социальных отношений и социальных ориентиров на профессиональное самоопределение школьника.

Таким образом, исследования профориентации школьников по охарактеризованным в работе направлениям формируют комплексное понимание профориентации школьников как социального феномена, что можно считать теоретическим основанием социологического подхода к профориентации школьников.

\section{Библиографический список}

1. Дементьев И.В. Профессиональная ориентация: анализ научных подходов // Кіраванне у адукацыі. 2008. № 11. С. 56-62.

2. Маркс К. Размышления юноши при выборе профессии // Маркс К., Энгельс Ф. Сочинения. 2-е изд. Москва. 1975. T. 40 .

3. Парсонс Т. Профессии и социальная структура // Социология. 2015. Вып. 4. С. 153-170.

4. Пономарев И.В. Дискуссионные вопросы кросс-культурных исследований влияния грамотности на когнитивное развитие и концепция симпрактического общества // Культурно-историческая психология, 2007. № 4. C. 59-67.

5. Ц Цвык В.А. Профессионализация как социальный процесс // Вестник РУДН, серия «Социология», $2003 .-$ № 4. C. 258-269.

6. Социальная стратификация современного российского общества / Под ред. З.Т. Голенковой. Москва. 2003. 